\title{
Civil Contract as an Evidence in Avestan Criminal Procedure
}

\author{
Shukhrat Hamroyev, Aleksey Parfyonov* \\ Faculty of Law, Russian-Tajik Slavonic University, 30 M. Tursunzoda St., Dushanbe, 734025, Tajikistan
}

\begin{abstract}
The paper considers the statutory concept of the civil contract as a form of evidence used by the ancient Tajiks in Avestan court proceedings, particularly with regard to findings, typology and responsibility for violation of the contract in part of Vendidad. The history of contracts as a form of evidence in Avestan court proceedings is the key component of political and legal institutes within the historical development of Tajikistan, which was characterized by worldview, political and cultural values of the society in a certain era of its development. Therefore, the study of this main institute of criminal proceedings always remains relevant. The study provides the retrospective analysis of the contract as a form of evidence in Avestan court proceedings during the period of the Zoroastrian civilization. The study results in basic principles and ways of implementing the contract as a form of evidence in Avestan court proceedings.
\end{abstract}

\section{Introduction}

Avesta is not only the outstanding historical, legal, spiritual and cultural value, but also the main heritage of the Tajik people and the basis for its recognition as the most ancient nation by the global community. Being the main source of the law of the ancient Tajiks, the Avesta consists of several parts with the Vendidad [1] giving the fullest picture of social structure and legal institutes, including twenty two fargandas (chapters). In fact, this part is the legal component of the Avesta [2, pp. 68-73]. At the same time, the Avesta is also the main source of criminalistic knowledge in historical Tajikistan in the period of the Zoroastrian civilization [3, pp. 153-164]. It is not fortutous that this part of the Avesta is called the ancient law of the Central Asia. The legal norms of this historical and legal document are systematized in the Vendidad - 'Law against devas'. The Avesta is a comprehensive legal source containing legal norms of the criminal law, water law, judicial law, etc. [4, pp. 52]. Similar features may also be found in other ancient legal documents (the Code of Hammurabi, the Law in Tables, the Berlin Documents, the Bakharist Code and even the Laws of Manu), which, unlike the Avesta, were compiled by a ruler and a legislator. However, the distinguishing feature of the Avesta as a legal source includes the fact that it was not compiled by a specific legislator or a ruler performing functions of the legislator in ancient times.

It should also be noted that the importance of the Avesta as the first and only written source in the history of the Tajik law may reflect real conditions of political, social and economic situation of the ancient Tajiks, which will indicate the identity of the nation alongside with the identity of Avestan court proceedings.

\section{Research Methods}

The framework of the study included historical and comparative methods. The study also included such general and specific scientific methods as the system analysis, structural, comparative, technical, dogmatic, sociological analyses, statistical methods, methods of comparative law.

\section{Results and Discussion, Findings}

\section{Historical and legal aspect.}

The Zoroastrianism in Persia was developed long before the formation of the Achaemenid Empire. During the reign of the Achaemenid dynasty the Zoroastrianism became the main and official religion of this empire. This situation is clearly reflected in the famous Declaration of Human Rights written by Cyrus the Great, the founder of the Achaemenid Empire, which reached our days in the Babylon language. The document says: "I am Cyrus, from now on, till (Ahura) Mazda grants me the kingdom favor, I will impose my monarchy on no nation. ...". The mention of AhuraMazda as the presiding deity and the patron saint of imperial power in the official document, undoubtedly, demonstrates that the Zoroastrianism already under the reign of Cyrus was the official religion of the Akhemenidsky Empire. If that is so, then the Akhemenidsky Empire applied the Avestan legal system. The broken texts of the Avesta [5, pp. 122; 6, pp. 219] were codified in the Parthian Empire (256 BC-224 AD) under the reign of the Parthian King Vologos 1 (50-76 $\mathrm{AD})$.

Meanwhile, the Zoroastrian law reached its full flowering in the Sasanian Empire with the developed legal system. Many public relations in this country were

\footnotetext{
* Corresponding author: parfenov_alexey@mail.ru
} 
governed by the Avesta - a religious and legal monument of the Zoroastrianism, as well as by the Sasanian Codes of Law [7, pp. 47; 8, pp. 153].

\section{Civil aspect}

During that era the contract entity as a major social regulatory system, its civil and evidential significance formed the basis for the Avesta civil law since the central place among the civil laws of the Avesta was taken by legal norms directly devoted to contractual content, classification and fidelity [9, pp. 34]. At the same time, during the considered period the civil contract also acted as one of the forms of evidence in criminal proceedings. This point of view reflects important ontological and gnoseological aspects of the civil contract and features of its functioning during the validity of the Zoroastrian Law in the history of Tajikistan. In this regard, the history of law indicates various interpretations of the issue of functioning of the Avesta civil contract. Thus, A.G. Kholikov considering the contract within the system of the Avesta civil law, distinguishes six types of contracts [4, pp. 108].

In science terms, the typology given by A.G. Kholikov only refers to one type of contract - the contract of guarantee, and does not classify different types of contracts. In general, these contracts can be characterized as oral contracts.

It should be noted that concerning other four types of contracts of guarantee (guarantee with a sheep, guarantee with cattle, guarantee with slave, guarantee with (entire) area) it may be concluded that, most likely, they refer to the guarantee of contractual obligation being the prerequisite for a guarantee institution.

The Avesta clearly describes the existence and functioning of contracts in line 2, fargarda 4 of the Vendidad, where to the question of Zaratushtra: "How many in number are thy contracts, O Ahura Mazda?", Ahura Mazda answered: "They are six in number, $\mathrm{O}$ holy Zarathushtra. The first is the word-contract; the second is the hand-contract; the third is the contract to the amount of a sheep; the fourth is the contract to the amount of an ox; the fifth is the contract to the amount of a man [person]; the sixth is the contract to the amount of a field, a field in good land, a fruitful one, in good bearing" [10, pp. 438].

In addition, the Avesta (adapted translation, study and comments by E.V. Rtveladze, A.Kh. Savidov, E.V. Abdullaev), section "Fargard 4. Contracts and offenses. Ia refers to types of contracts and punishment for their violation" [11, pp. 97-99]. It also includes measures for violation of these types of contracts (5-16 parts of Fargard 4) [11, pp. 97-99].

Traditionally it does not divide all contracts into groups, i.e. does not classify them, which is caused by the fact that the given comments regarding the structure contracts are only applicable to one type of contracts the contract of guarantee. It also illustrates the fact that the Avesta clearly distinguishes between the form of a contract and its typology, which makes the analysis of civil contracts of the Zoroastrianism complicated. However, this does not mean that the Zoroastrian Law neglects other types of contracts (sale-purchase, loan, employment, donation, etc.) and their functions. According to researchers, the Avestan Law contains legal standards referring to certain types or classes of contracts, such as: sale-purchase, loan, employment, rent and even aleatory contracts, etc.

The authors believe that the Avesta does not simply mention certain types of contracts but gives their classification both in terms of their conclusion and the value of guarantee. The main feature of contractual relations in the Avestan Law is the fact that the contract creates an obligation depending on the specified value of the collateral. Characterizing the legal culture of the Avestan era it should be noted that the law of obligation had not been known yet, and all contractual relations were governed by the conventional law, and improper performance or violation of contractual obligations during that era was regarded as a religeous offense.

It would be right to say that during the era of the Zoroastrian Law the contractual law was, in fact, replacing various forms of the law of obligation since during that historical period the private law used various forms of concluding a contract and their combination. This is strongly exemplified in written contracts as one of the most important forms of contractual relations in the Zoroastrian Law. At the same time, the civil contract implied not a simple agreement between the parties, but the need to conclude a specific document declaring rights and obligations of the capable parties only (or the person representing the interests of the owner) and being the subject of mandatory execution. It should also be noted that the contract in the Zoroastrianism was understood as not only the document of transaction, but also the moral value on regulatory compliance, while the non-compliance of a contract was considered a sin. Besides, an important characteristic of contractual relations of the Zoroastrian period is the need to use voluntary and compulsory ways of securing obligations or their combination. The concept 'contract of guarantee' and various forms of its use in contractual relations does not only cause the difference of obligatory legal relations of the Zoroastrianism from other legal systems of that period, but also defines this type of contract as the developed form of relations where each participant is responsible for assumed liabilities. Moreover, in case of violation of contractual terms the parties were protected not by the parties as such taking into account their authority or privileges as it was accepted in some ancient empires of the East, but through court claims under the lawsuit regarding the restoration of the claimant's violated rights.

\section{Criminal procedure and criminalistic aspect}

The analysis of the civil contract as a form of evidence in the Avestan Law shows that the adherence to the contract (oral or written) among the Central Asian people was considered as a particularly valuable quality of a person. In the Avestan criminal law the contract in its narrow legal meaning was called patimana (from ancient Iran pati-ma-na). The Pehlevi Book About the Righteous Viraz, the original copy of which dates back to the first centuries $\mathrm{AD}$, tells about the Zoroastrian righteous person Viraz who, once being to hell, saw "the 
soul of a person who was killed with fast arrows, stones and clods of earth"; as it turned out, it was "the soul of a sinner who often violated contracts with righteous and guilty people, while both contracts are valid: both with righteous and with guilty".

Besides, the fargarda 67 of the famous book Ardavirafname says: "When in hell (Ardaviraf), I saw a man in prison who was hung upside down (his head being down) and his eyes were punched with iron nails. I asked who this person was? I was answered that this is the body of a person who was trusted and given the power of justice. But he failed to fulfill his duty in relation to people, moreover, he was committing sins" [12, pp. 61].

As noted above, in the Vendidat the concept of contract takes one of the central places. Personification of the contract, Mithra, the third fragarda (III, 1) refers to it as the most esteemed deity. The fourth fragarda considers six types of contracts depending on their pledge (IV, 2-4) and three - depending on their subject (IV, 44-45); both in case of concluding and trial contracts (ordeal), in case of suspicion on their violation people had to give the oath to the Mithra (IV, 54-55) [13, pp. 95-100].

In compliance with the Avestan legal proceedings, in cases without any witnesses and no opportunity to prove the guilt of a suspect, people appealed to deities and angels, with whom they had some kind of conditional (divine) contract since being all-seeing and all-knowing such divine creatures knew who exactly was guilty and could help to establish the truth. In this regard, to avoid a sin of punishing the innocent person and to prevent the offense, the guilt of a suspect was proved through nature elements. As A.G. Khalikov describes it, such trials by ordeal were not invented by the Zoroastrians but were passed down to them from ancestors [10, pp. 109].

The so-called 'Elephantine Papyri' dated 464 BC also indirectly demonstrates that in case of legal disputes among ancient people living in the territory of Tajikistan (as well the majority of other ancient nations) people had to take an oath naming the most esteemed deity [10, pp. 110]. In certain cases an objuration was considered and thus people applied trials falling within the competence of the ordeal chaired by the Rat [13, pp. 95-100].

The ordeal (from Anglo-Saxon ordol, Latin ordalium - sentence, court) in its broad sense is the same as the 'Judicium Dei' (Latin for 'by judgement of God'); and in its narrow sense - the ordeal by fire and water. Ordeals are considered one of the types of the archaic law, and similar trials are mentioned in the Code of Hammurabi [14]. The trial by ordeal is an ancient judicial evidence relying on the opportunity to appeal to the deity for help to solve disputes among people and establish the guilt [15]. Traditionally, the Sasanian Law Code and other texts of historical Tajikistan defined the trial by ordeal with the general term 'Var'. Its ancient form (varah) is testified in the Avesta in the same meaning.

According to the Zoroastrianism, everything in this world is the result of the response of the God and his angels to legal behavior of a person. If people misdeal, break an agreement, deceive each other, commit offenses and crimes, then the Mithra, called upon by Ahura-
Mazda to control the fulfillment of contracts and standards of behavior, flies into a rage and punishes people. Such legal thinking was typical for the ancient Zoroastrianism. Later these forces of nature were transformed into the trials by ordeal representing hot (fire (as it is noted in chapter XX of Shayast-na-shayast: "The one saved by fire is saved forever and the one condemned by fire is condemned forever" [16]), boiled water and molten metal) and cold (water) trials (vazhzhi garm va sard), which judicially establish the guilt [10, pp. 35] and serve the source of evidence.

Unlike western Greek and Roman procedural law of the classic era, which never used the trials by ordeal (original meaning: the oath was applied as evidence), prior to the adoption of Islam in the territory of historical Tajikistan such archaic institute as the trial by ordeal was a lawful form of a lawsuit if within a standard process the decision-making was impossible [10, pp. 38].

The trials by ordeal in the Avestan legal proceedings represented trials by fire, water or other forces of nature. The persons in dispute volunteered to make something that would naturally be disastrous for them, but due to direct involvement of the Deity it will be harmless.

The most ancient parts of the Avesta mention a trial by ordeal, which confirms the antiquity of this tradition. According to Dinkard, the nask 18 'Sikatum nask' was mainly devoted to the issues of var - a trial by ordeal. Unfortunately, the history failed to preserve any record of this part of the Avesta.

Several types of ordeals are mentioned in the text of the Avesta, which survived to our days. First of all, this is the ordeal by fire (Yasnas 31, 3, 943,$4 ; 47,6 ; 51,9$; $12,3)$. It was also mentioned in the Legend of Siyavush by Firdausi, where the first one cleared himself from the slander of Sudabe with fire. During the trial by fire a person was holding a hand on fire by passing through the lit fire in a shirt only (which sometimes was covered with wax), or holding a hot iron. The Yasna ghat 51, 9 refer to the ordeal by molten metal, and the Denkart stanzas $644,14-22$ mention the trial by molten metal poured on the chest, which is mentioned as one of 33 methods of ordeal procedure typical for the Zoroaster.

The Yasna ghat 30, line 7 says: "Those are right who believe in you and will survive the trial by metal". This line obviously mentions the trial for fidelity or falsehood of a suspect's statements [10, pp. 97].

According to the legend, Aturpat-i Makhraspand survived this type of trial by ordeal for the sake of a tribute to the Zoroastrian religion. The story by Adurbad, the son of Makhraspand, in the Shayast-na-shayaste narrates about the importance and principles of the ordeal of molten metal: "Let him honor the molten metal everywhere and always, and to honor the molten metal is to make heart so clean and innocent (for) metal that if poured the molten metal does not burn down. Adurbad, the son of Makhraspand, obeyed this in a way that when the molten metal was poured on his clean body and heart, it was so pleasant for him as though it was milk. And if the metal is poured on the body and heart of liars and sinners, they burn down and die. Let him not sin due to molten metal, a (person) gets burnt down" [16]. 
Thus, this source discloses the importance of metal as a divine element with judicial prerogatives and legalizes its use in the ordeal of molten metal. Being the element of judicial evidence, the metal at a certain moment serves as punishment to offenders thus punishing them through ordeals.

The third way, known from the Avesta, is the ordeal of boiling liquid, water or oil, or on the contrary, ice water. As J. Dustgokh notes, the sources refer to rare data on 'vari otash' - ordeal of fire; 'vari nirang' similar to the ordeal of metal; 'vari ravgan' - ordeal of molten butter, etc. [17, pp. 612]. There remained some historic facts and stories about these types of ordeals (ordeal of Siyavush with fire in Shakhnam [18, pp. 316] and Adurbad, the son of Makhraspand in Shayast-nashayast) [16].

Hashim Razi believes what the Avestan society applied at least 30 types of ordeals $[19 ; 20 ; 21]$. As A.G. Khalikov writes, two forms of ordeals were typical for historical Tajikistan: the ordeal of molten metal, which was called the hot ordeal ('vari garm') and the ordeal of cold things - water (vari sard'). According to the Avestan scriptures, 'var' is the ordeal with sacred intoxicating drink - haoma, barsam or other poisonous liquid [10, pp. 96]. According to J. Dustgokh, the Avesta uses the term 'var' only in Rashn yashta (lines 3-6) and Hurd Avesta (Ofaridgoni Gakhanbor, line 9). It is not mentioned anywhere else. However, other parts of the Avesta tell about ordeals used to establish the truth.

The 'hot' ordeals included ordeals of hot iron, which was reflected in the Persian text of Saugand-noma - the ordeal similar to the Indians. Other forms of ordeals include placing the accused person or an object subject to conjuration into the river or lake. Historical Tajiks believed that the waters of the lake Frazdanav accepted only what is thrown by the innocent but threw out the 'gift' of the guilty one. The legendary reflection of this ordeal may be found in the story about seven miracles of Jamsheed (Yama-Hshayety), namely about the sixth miracle: the guilty sinks whereas the innocent remains on water surface and approaches a figure on a bridge across the river symbolizing the judge [22, pp. 152]. The Avestan tradition also includes the ordeal by three sacral branches of tamarisk. The ordeal by the intake (drink) of ritually prepared liquid was also practiced since the ancient times. The Avesta mentions the ordeal by the juice of plants used for sacrificial libations and the ordeal by water containing sulfur and gold capable to tell the truth [10, pp. 98].

As previously noted, even during the era of the last Sasanians the ordeal court (datastan pat var) was one of accepted forms of legal proceedings, however rather 'extraordinary' in the territory of historical Tajikistan. Traditionally the lawsuits were settled in civil courts, which awarded judgement based on procedural consideration of the case following the procedure described above. According to the Code of Laws, only in case when the traditional court proceedings came to a standstill, the judges were awarding ordeals. Such features are found in Elephantine Papyri of the Achaemenid era [23, pp. 87-94].
The court decision on ordeal to the litigant was recorded in a special document called uzdat-namak or namak-passak. The party subject to ordeal or an oath had to declare its consent and put its signature on this document [24, pp. 290]. According to the decree of rats regarding the officials of the district Artashakhr-Hvarre contained in the Code of Laws dated to the reign of Khosrow Anoshirvan, the ordeal was considered lawful only if it was conducted following the recorded judgment and in compliance with this document, which, obviously, described the type of ordeal to be applied. At the same time, the judges, both databars or magupats, had no right to award an ordeal and appoint the date for this procedure without the rat's participation in decisionmaking [10, pp. 94].

Due to differences in ordeal rituals the different types of ordeals had no value in general legal relations, the Code of Laws usually did not include the type of ordeal, and even where such references are available, they are random and do not give any idea regarding types of ordeals applied in legal proceedings of the Sasanian period.

\section{Conclusion}

Based on the above it is possible to come to the following conclusions.

The ordeals in the territory of historical Tajikistan in the period of the Zoroastrian civilization as a result of agreement between judges with the highest forces were quite typical in the context of the ancient legal development. The ordeals were applied both to establish the guilt and to testimony a witness. As R. Larivye in the comparative study The Trials by Ordeal in Europe and India noted, the ordeals "are part of the evolution of the legal system almost in any society". Except bringing oaths the ordeals could be used in the ancient and early medieval world "in case of no other humane [ways of receiving] evidence" [1, pp. 55]. At the same time, R. Larivye notes that since 6-7th centuries AD both European and Indian legal texts emphasize scepticism concerning ordeals [1, pp. 55]. The Zoroastrian legal tradition does not reflect similar scepticism.

Certainly, the trial by ordeal as a form of the evidence of guilt is irrational and unacceptable, but taking into account the level of human development regarding law and mechanism of evidence, then such primitive procedural thinking was typical for people of that period. Later the ordeal was used for centuries in Europe (Salic Law [25], Saxon Law [26]). If such thinking and methods are analyzed further, then it turns out that they are not alien to a modern legal system. The strive to transfer functions of establishing a guilt or innocence to other forces in many respects was caused by the desire of ancient people to objectively and impartially solve the disputes Today the mankind also strives for such objectivism and impartiality of preliminary investigation and legal proceedings, but, unfortunately, there are many urgent problems regarding this topic.

In general, all factors given above played a key role in defining the contractual law as the type of evidence in the Avestan legal proceedings regarding criminal cases 
and civil disputes, as well as in the legal system of the Zoroastrianism in general.

\section{References}

1. Avesta: Law against devas (Videvdat SPb.: Publishing house of Polytechnic University, 2008)

2. Vendidad / tarchuma, vozhanoma, yoddoshtkho Hoshimi Razi: in 4 parts (Tekhron, 1376)

3. B. Gafurov, The Tajiks (Moscow: Science, 1972)

4. Avesta: Kukhantarin surudakho-e Eroni boston, Guzorish va pazhukhishi Chalili Dustkhokh (Tekhron: Murvorid)

5. A.K. Rzayev, Study of the history of political and legal doctrines (Baku: Azerneshr, 1986)

6. I. Safarov, Legal system of the Samanids $\left(9-10^{\text {th }}\right.$ centuries) (Dushanbe: Irfon, 1999)

7. F.T. Takhirov, A.G. Halikov, Civil laws and institutes of the Avesta and Zoroastrism, Zoroastrism and its value in development of civilization in the Middle East (Dushanbe, 2003)

8. V.G. Lukonin, Culture of Sasanidsky Iran. Iran in the $3-5^{\text {th }}$ centuries. Study of cultural history (M.: Nauka, 1969)

9. A.G. Khalikov, Legal system of Zoroastrism (ancient law) (Dushanbe: Maorif va Farkhang, 2005)

10. A.A. Parfyonov, Videvdat as the main cultural source of the criminal law in historical Tajikistan, Language, culture and society at the intersection of civilizations: proceedings of the $12^{\text {th }}$ International Scientific Conference. (Tsukuba, Japan, 2015)

11. M.A. Korostovtsev, I.S. Katsnelson, V.I. Kuzishchin, Ancient East history reader: In 2 parts, P.2: study manual (M.: Higher School, 1980)

12. Ardavirafnoma: Bikhisht e duzakh oyin-e mazdoyasno. Peshguftor вa tarchima Rakhim Afif. Tue, 1372-207, pp. 61.

13. A.A. Parfyonov, Ordeal as a form of evidence and verification of evidence during the development of the criminal law in Tajikistan under the influence of Zoroastrian civilization, Bulletin of Pedagogical University, 6 (61), 95-100 ( 2014)

14. Encyclopedia. Retrieved from: : https://ru.wikipedia.org/wiki/\%D0\%9E\%D1\%80\%D 0\%B4\%D0\%B0\%D0\%BB\%D0\%B8\%D0\%B8

15. K. Batyr, History of state and the foreign law. Retrieved from: http://www.gumer.info/bibliotek_Buks/Pravo/batur/1 1.php - 7/3/2015

16. O.M. Chunakov, Shayast na-shayast, Zoroastrian texts. Judgments of mind spirit (Dadestan-i menogand khrad). Creation of the basis (Bundakhishn) and other texts. (Moscow, RAS East Literature Publishing House, 1997)

17. Monuments of ancient manuscripts of the East. Retrieved from: : http://zoroastrian.ru/node/798 21.10.2014

18. J. Dustkhokh, Avesta: Kukhantarin surudakhoi Eroni boston, Guzorish va pazhukhishi Chalili Dustkhokh (Dushanbe, 2001)

19. A. Firdavsi, Shokhnoma: Legend of the Siyavush (Dushanbe: Maorif, 1990)
20. Hashim Razi, Avesta: Kukhantarin ganchina-e maktubi Ironi boston, Avesta: The most ancient hand-written pearl of the ancient Iran (Tarchima va pazhukhishi Hoshim Razi. Tehron, 1379)

21. Razi Hashim, Vendidad / tarchuma, vozhanoma, yoddoshtkho Hoshimi Razi: in 4 parts (Tekhron, 1376)

22. I.M. Steblin-Kamensky, Avesta: selected sacred songs (Dushanbe: Adib, 1990)

23. Para. Hiv. Horn. - Fran. 437 (Bartholomae. Zend Hes)

24. A. Verger, L,amministrazione della glusticia nei papyri aramaici di Elefantia. - «Atti della Accademia nazionale dei Lincei», Ser. VIII, Rendiconti (Cl. di Scenze morali, ator. e filol) XIX, 3-4, 87-94 (1965)

25. A.G. Perikhanyan, Society and law in Iran during the Parthian and the Sasanidsky periods (Moscow, 1983)

26..F. Semyonov; N.P. Gratsiansky, The Salic law (Moscow: State Pedagogical Institute, 1950)

27. V.M. Koretsk, The Saxon Speculum Iudiciale. Monument, comments, study (Moscow: Science, 1985) 